\title{
Языковая политика Российской Федерации ${ }^{1}$
}

Владимир Толстой

(c) Толстой Владимир Ильич председатель Совета при Президенте Российской Федерации по русскому языку, советник Президента Российской Федерации по вопросам культуры, президент Международной ассоциации преподавателей русского языка и литературы (МАПРяЛ), директор музея-усадьбы Л.Н. Толстого «Ясная Поляна" (г. Москва, Россия), vitolstoy@gmail.com
Российская Федерация - многонациональное государство. Наша Конституция начинается со слов «Мы, многонациональный народ Российской Федерации, соединенные общей судьбой на своей земле...».

Специалисты насчитывают более 100 языков народов России. Из них 54 - это языки малочисленных коренных народов, 32 языка имеют письменные традиции. При этом речь идет именно об автохтонных народах России и их языках. Эти особенности нашей страны определяют цели и характер языковой политики России, ставя в ее центр именно внутренние проблемы и задачи.

В Российской Федерации всем ее народам гарантировано право на сохранение родного языка, создание условий для его изучения и развития. В силу федеративного устройства страны Основным законом предусмотрена возможность для республик в составе Российской Федерации устанавливать государственные языки республик. В Дагестане, например, государственными объявлены все 14 языков Дагестана.

Единство, целостность и культурный суверенитет России обеспечивается статусом русского языка как государственного языка Российской Федерации.

Нормы Конституции относительно языков народов Российской Федерации разви- 
ты в двух федеральных законах: «О языках народов Российской Федерации» (1991 г.) и «О государственном языке Российской Федерации» (2005 г.). Временная разница в принятии этих двух законов отражает происходившие в то время поиски оптимальной структуры языковой политики в России.

Сегодня языковая политика России имеет демократический, плюралистический характер. Одна общегосударственная функциональная домината - русский язык - сочетается со статусными языками национальных республик в составе России. Причем в зависимости от конкретной языковой ситуации есть республики, где русский язык сочетается с одним, двумя, четырьмя и более национальными языками этих республик. При этом в других субъектах Российской Федерации - областях и краях - реализуется однокомпонентная модель языковой политики, когда бытует русский язык в его различных формах. В отношении языков малочисленных коренных народов России в нашей стране реализуется экстерриториальная (дифференцированная) модель языковой политики.

Такая классификация соответствует современному положению языковой политики в Российской Федерации и определяет пути дальнейшего распространения, расширения социальных функций статусных (государственных) языков, хотя, конечно, для такого расширения социальных функций необходимо однонаправленное положительное действие многих условий и социальных факторов: экономическое благополучие, этническое самосознание, ценностные ориентации носителей языков, материальные условия для расширения их функций в разных сферах коммуникации.

Наиболее сложной проблемой российской языковой политики является расширение социальных функций государственных и родных языков народов Российской Федерации.
Решение этой проблемы имеет не только гуманитарное и культурное значение, но и напрямую связано с вопросами национальной безопасности: исторический опыт конца XX - начала XXI вв. показывает, что именно языковые проблемы становятся зачастую поводом для роста националистических сепаратистских настроений.

Вопросы языковой политики внутри страны постоянно находятся в центре внимания всех уровней государственной власти от Президента Российской Федерации до руководителей республик, краев, областей.

В прошлом году Президентом Российской Федерации В.В. Путиным было принято решение о создании Фонда сохранения и изучения родных языков народов Российской Федерации. Фонд вместе с Федеральным агентством по делам национальностей и Министерством просвещения Российской Федерации должен оперативно и прицельно реагировать на возникающие проблемы и находить пути их решения.

Требуют безотлагательного решения и проблемы сохранения языков коренных малочисленных народов Российской Федерации, которые испытывают негативное воздействие не только процессов урбанизации, но и изменения климата в зонах традиционного расселения этих народов (районы Крайнего Севера, Заполярье).

Государственный язык Российской Федерации также нуждается в защите, прежде всего от вульгаризации и засилья избыточных англицизмов. Сохранение и развитие русского языка как языка подавляющего большинства граждан нашей страны обеспечивается профильными ведомствами в составе Правительства Российской Федерации, органами власти субъектов Российской Федерации, системой образования, учреждениями культуры. На уровне Президента страны создан и действует Совет по русскому языку, в сферу внимания которого входят все аспекты функционирования и состояния русского языка. 
На заседании Совета 5 ноября 2019 г. ную остроту эти процессы приобрели побыло принято решение о разработке и утверждении корпуса словарей и справочников, которыми обязаны пользоваться все при использовании русского языка как государственного языка страны. Будет формироваться цифровой Национальный словарный фонд, который дополнит динамично развивающийся Национальный корпус русского языка.

Решение о праздновании в 2024 г. 225-летия со дня рождения А.С. Пушкина, несомненно, позволит привлечь внимание общества к задачам сохранения чистоты и развития русского языка.

В набольшей степени в поддержке Российского государства русский язык нуждается в качестве мирового языка, языка русского зарубежья. Мы являемся свидетелями радикального сокращения, сжатия пространства русского языка. Отчасти эти процессы носят объективный характер, отчасти являются результатом антироссийской политики ряда стран. Особен-

сле 2014 г.

Продвижением русского языка в мире занимаются как государственные структуры: МИД России, Россотрудничество, высшие учебные заведения страны, так и общественные организации, такие как МАПРяЛ, фонд «Русский мир». Подходы государства к этой сфере деятельности зафиксированы в утвержденных Президентом России Концепциях государственной поддержки и продвижения русского языка за рубежом и «Русская школа за рубежом». Сегодня поставлена и решается задача расширения набора инструментов государственной языковой политики в ее международном измерении.

Несмотря на существенные различия языковой политики России и Франции современный этап развития глобального мира ставит перед нами во многом сходные задачи, и расширение взаимодействия в этой сфере дает всем нам дополнительные возможности.

\section{Примечания}

${ }^{1}$ Выступление на российско-французском лингвострановедческом семинаре «Языковая политика во Франции и в России: проблемы и перспективы», проходившем 11-12 декабря 2019 г. в Москве на факультете журналистики МгУ имени М.В. Ломоносова. Семинар проводится под эгидой российско-французского форума гражданских обществ «Трианонский диалог» в сотрудничестве с Федеральным агентством по печати и массовым коммуникациям (Роспечать), Министерством просвещения России и Министерством культуры Франции 